\title{
INFLUENCE OF COVID-19 PANDEMIC ON WOMEN ENTREPRENEURIAL SUCCESS IN OYO STATE
}

\author{
Hambolu, Agnes Taiwo \\ Kwara State University, Malete, Ilorin
}

\begin{abstract}
This paper is focused on the influence of covid-19 pandemic on women entrepreneurial success in Oyo State, Nigeria. It discussed the origin of Coronavirus; how deadly and infectious the virus is. The paper further discussed the rate at which the virus was spreading and killing people all over the world. It also discussed how the Coronavirus affected the economic, religious and, social activities of women in the state. The paper concluded that the lockdown to stay-safe at home had to be observed for people to be protected from being infected and the infected people be quarantined for medical attention to avoid the spread of the virus. It also recommended that government should release money to the commercial and microfinance banks with specifications and directives on how loans will be given to the eligible people. It also recommended that government should organize seminars, workshops and training on small scale businesses for the public especially women to eradicate poverty. The paper further recommended that government should set up a committee that will help in distribution of financial donations from agencies and other palliatives through the bank officials and National Population Commission Officials.
\end{abstract}

KEYWORDS; covid-19, women entrepreneurial success, government.

\section{INTRODUCTION}

Covid-19 pandemic is a virus that ravaged all over the world. It was caused by severe Wuhan, China in December, 2019. The declaration of the covid-19 outbreak by the World Health Organization (WHO) as an emergency that calls for international attention on January 30, 2020 was recognized as pandemic on March 11, 2020. The virus that emanated from China caused a lot of people to lose their lives, especially women of middle age and older women. The spread of the virus did not stop in China but spread across the whole world. The rate at which people were infected with the virus led to high increase in mortality rate especially in countries like China, Italy, Spain, Russian, Japan and Brazil are few among many countries of the world. Nigeria, in Africa was not exempted. Several efforts made by medical researchers to provide cure at the beginning of its outbreak proved abortive.

However, the increase in the mortality rate of the infected people made the World Health Organization (WHO) to compulsorily advised total lock down in Europe in January, 2020. The total lockdown to stay safe in three locations in Nigeria; Abuja, the Federal Capital Territory, Lagos State and Ogun State became a law that spread to other cities and towns in Nigeria after the pronouncement was made by President Mohamadu Buhari on Friday, 20th March, 2020.

The pronouncement to stay safe at home by the authority was strictly enforced to the extent that there was partial or no religious activity. Business transactions were on the low ebb. The major highways were deserted. Only the essential workers (health, NCDC and security 
officials) were allowed to move freely. The educational institutions were shut down. Banks were involved in skeletal operations. The domestic and international airports were shut down. The Port Authorities were locked down. Psychologically, people were affected because of fear of unknown and instead of the disease to be eradicated, the rate at which people were infected was on the high increase.

\section{The Effect of Covid-19 pandemic on Women Entrepreneurial success in Oyo State Economy Activities}

The lock down affected the World Economic activities, Religion activities, Social activities to the extent that there were drastic declines in business activities. Several women lose their jobs. There was severe increase in the poverty level of the people. Women in Oyo State are among the several women that were worst hit in Nigeria.Nigeria, a developing country had been struggling for the sustainability of her economy to witness a rapid economic increase but experienced a drastic economic meltdown and stagnancy because of the lock down in the country to curb or eradicate the spread of the virus.

According to the address by H.E. Mohammadu Buhari, President of the Federal Republic of Nigeria on cumulative lockdown order of Lagos and Ogun States as well as the Federal Capital Territory on COVID-19 pandemic at the state house, Abuja on Monday, April 27, 2020. The three states are however the country's economic and financial powerhouse. Thus, their lockdown is expected to have significant economic implications in other parts of the country (Brief 2 of Nigeria Covid - 19 pandemic). The lockdown particularly affected Oyo State women entrepreneurs because Lagos and Ogun States are major places they go for business transactions.

President Mohammadu Buhari said in his second address to the nation on April 28, 2020 that the lockdowns, which had been due to end on Monday, May 4, 2020 was extended for another two weeks. He also ordered that new nationwide measures be implement against the spread of Covid-19. These includes night-time curfew and mandatory use of face masks. His intention was to ease the economy, but the measure complicated the economic activities because people could not get themselves involve in business activities online. They were only carrying out their business transactions at night; they had to travel at night from one point to another. The population of the three states (Lagos, Ogun and the Federal Capital Abuja) which constitute over 25 million people were hindered from carrying out their duties and business activities. The Board of internal Revenue, Oyo State 2018 reports stated that the income generated from women entrepreneurs was about $48 \%$ and the entire labour force of Oyo State constitutes about $68 \%$ of women Entrepreneurs. The income that supposed to be generated from this sector had actually gone down because of hindrance by the government to carry out their businesses or entrepreneurial activities.

\section{Religion Activities}

According to Salve (2020), spirituality is the foundation of human existence and getting more attention in Global Health but Puchaiski (2009) defines spirituality to be that aspect of humanity that refers to the way individuals seek and express meaning, purpose and experience their connectedness to the moment, to self, to others, to nature and to the significant or sacred. Covid-19 created a worldwide threat to the point that Africans began to forget their traditional and communal lifestyles. People that are closely related do not 
associate with their people any longer. Coronavirus had negative effects on people's interrelationship to the extent that a Father, Mr. Akinyemi on $20^{\text {th }}$ of April, 2020 rejected his son that arrived from Lagos to Ekiti to meet with his family members.

The Covid-19 pandemic had affected religious activities in various ways. These includes the cancellation of worship services of various faith, as well as the cancellation of pilgrimages to holy lands. The Easter and Ramadan celebrations were observed at individual homes. There was no religious gathering of any nature. Several churches and mosques instructed their followers to gather at cell points. Some churches referred to it as house fellowship. Most followers of the Christian faith most times, pay their tithes and offerings as well as other donations from their various locations online or through mobile banking. The ban on religion activities by the government directly or indirectly affected the women entrepreneurs because people no longer gather in large number to worship. In some places of worship, women seem to take the larger number including old and young. Savings and weekly contributions made by some women group came to a halt because some of them engage in some other activities when they gather for religious gatherings apart from spiritual nourishment.

\section{Loss of Job}

The issue of stay safe at home pronouncement by the authority to protect one from been infected with the virus also made many private sectors or organizations to reduce their work force because they were not financially buoyant to maintain or pay the salary of their staff. Many private schools in Ibadan retrenched their staff and ask them to reapply after the issue of covid-19 pandemic is completely eradicated. Access Bank down sized their work force and asked them to wait till the pandemic is over. The effect on the health sector cannot be overemphasized. Several private hospitals were shut by the government because of their interference with people that had been infected with the virus. Alafia Hospital, Mokola, Ibadan is a reference point. Some of the hospitals had to sack their staff and ask them to return after the coronavirus pandemic is over. This particular action brought a great shock to many people which eventually claimed their lives. Many had an increase in their blood pressure, some could not recover from the psychological trauma. The resultant effects of the issues mentioned above affected the patronage of women entrepreneurs by their customers. Inhibited movement and insufficient cash flow posed great threat to business transactions in Oyo state.

According to Socialbakers (2020), the impact of covid-19 on Social Media Marketing revealed crucial insights into the changes and developments of behavior for both brands and users. She states that, the impact of covid-19 shows how the marketing landscape has changed due to the worldwide coronavirus pandemic. Yinka Ayefele Radio Station in Ibadan (Fresh FM) also suffered serious reduction in the patronage of women entrepreneurs that usually come for advertisement. Several religious organizations that usually air their programmes on the radio had to be suspended. Several jingles, announcement and social activities on the radio were put on hold. The drastic change in the patronage of the radio activities led to the down size of their staff. More so, high reduction in patronage of radio activities also forced the management to reduce their charges for all the programmes on air. Few of the private organizations in Nigeria especially in Oyo State who manage to retain their staff resolved to be paying half of their salary as well as cutting of certain allowances. 
The rate of hunger and poverty were on the high increase because people had exhausted their savings and there was no hope of getting money to solve their immediate needs.

\section{Social Activities}

The Covid-19 pandemic has had far-reaching consequences beyond the spread of the disease itself and the efforts to quarantine the people that are infected. The social and political implications are worthy of note. Medical experts and local authorities have warned the people to stare clear of social gatherings. They mandated the people observe stay-at-home order so as to prevent social gathering. Gatherings like birthday, wedding, burial and other ceremonies were eradicated. Official gatherings that will involve large number of people were replaced by teleconferencing. The federal executive council had to meet and deliberate online. Maintenance of social distance as well as strict observance of maximum number of ten in any gathering have affected the relationship of people in many ways.

Oyo state is a major commercial hub in the southwest. Most of her women usually engage in commerce or trading activities which makes them to engage in early marriage. Most wedding programmes could not hold during the period of lock down. This has led to lots of broken courtship and marriages. The little capital left with the unmarried and married women entrepreneurs was what they used to start afresh a business to keep live going which did not encourage them to have homes of their own or have time to carry out other social activities like burial ceremonies, birthday ceremonies, chieftaincy coronations and so on.

\section{CONCLUSION/ RECOMMENDATION}

Eye witness has shown that lock down of people to stay at home from being infected with covid-19 pandemics is experienced to protecting the life of individual that has not been infected with the virus and also to quarantine the infected people for medical care and to prevent it from spreading. which resulted to decrease in social economic activities, increase in poverty level due to lack of finance, loss of jobs and so on. Therefore, effort should be put in place for better economic growth. It should be a collective effort so as to achieve a huge success.

The acute shortage of finance of most women entrepreneurs and some private organizations can be solved by the government by giving loans with specifications and directives through commercial banks and microfinance banks to encourage women entrepreneurs and some private organizations to have access to loans without collaterals and little interest rate for quick and better transactions of their businesses. Workshops, Seminars and Trainings on small scale businesses that will not require huge capital and resources should be given to the public especially women entrepreneurs for quick turn out and success in their businesses. The training should include the technical-know-how of the business, where and the location of the business, methods of saving should also be involved for proper accountability.

Federal Government of Nigeria should set up a committee that will help to work with the National Population Commission, Commercial Banks and Microfinance Banks so as to collate the name of the customers, account number and bank verification number of their clients. The location of other group of people that do not operate an account with the establishments mentioned above should be sought. This will help in the distribution of the 
financial assistance and other palliatives that the government intends to provide so as to mitigate the economic meltdown caused by the lock down imposed by the government to curb the spread of the virus.

\section{Refences}

United Nations Development Programme (2020). Social Economic Impact of Coronavirus. Retrieved from https://www.undp.org on May 20, 2020.

Demographic and Social Statistics (2020). World Population and Housing Census Programme; Impact of Covid-19. Retrieved from https://www.unstats.un.org on May 23, 2020

Report of National Population Commission on 2006 Census- Jstor Retrieved from https: //www.socialbakers Retrieved on May 16, 2020.

Abiola, O. (2020) Full Speech of President Buhari on Covid-19 Pandemic. Retrieved from https://nairametrics,com on May 5, 2020.

Social Impact of Covid-19 Pandemic (2020). Retrieved from https://www.en.m.wikipadia.org on May 15,2020

National Bereau of Statistics (2016). Fiscal Statistic. Retrieved from https;//wwwinsideoyo.com Retrieved on May $5^{\text {th }}, 2020$.

BBC News: Coronavirus: Nigeria to ease Abuja and Lagos lockdown. Retrieved from https://www.bbc.com/news/world-africa-52445414 on May 5, 2020

Report: The impact of Covid-19 on Social Medial Marketing. Retrieved from https//www.socialbakers.com/blog/covid-19-impact-social-media on May 12, 2020

Board of Internal Revenue - Oyo State Government (2018). Retrieved from https://oyostate.gov.ng on May 20, 2020 